\title{
An Improved Speciation Method Combining IC with ICPOES and Its Application to Iodide and Iodate Diffusion Behavior in Compacted Bentonite Clay
}

\author{
Chuan-Pin Lee ${ }^{1,+}{ }^{\mathbb{D}}$, Yanqin Hu ${ }^{1,+}$, Dongyang Chen ${ }^{1}$, Enhui Wu ${ }^{1}$, Ziteng Wang ${ }^{1}$, Zijin Wen ${ }^{1}$, \\ Neng-Chuan Tien ${ }^{2, *(\mathbb{D}}$, Fan Yang ${ }^{3, *(D)}$, Shih-Chin Tsai ${ }^{2}\left(\mathbb{D}\right.$, Yunfeng Shi ${ }^{1,4}$ and Yi-Ling Liu ${ }^{5}$
}

Citation: Lee, C.-P.; Hu, Y.; Chen, D.; Wu, E.; Wang, Z.; Wen, Z.; Tien, N.-C.; Yang, F.; Tsai, S.-C.; Shi, Y.; et al. An Improved Speciation Method Combining IC with ICPOES and Its Application to Iodide and Iodate Diffusion Behavior in Compacted Bentonite Clay. Materials 2021, 14, 7056. https://doi.org/10.3390/ ma14227056

Academic Editors: Pohsiang Chang and Raj Mukhopadhyay

Received: 22 October 2021

Accepted: 15 November 2021

Published: 20 November 2021

Publisher's Note: MDPI stays neutral with regard to jurisdictional claims in published maps and institutional affiliations.

Copyright: (C) 2021 by the authors. Licensee MDPI, Basel, Switzerland. This article is an open access article distributed under the terms and conditions of the Creative Commons Attribution (CC BY) license (https:// creativecommons.org/licenses/by/ $4.0 /)$
1 School of Nuclear Sciences and Engineering, East China University of Technology, Nanchang 330013, China; bennis6723@139.com (C.-P.L.); hyqdrx@163.com (Y.H.); chen_dongyang2021@163.com (D.C.); 18679656079@139.com (E.W.); wzt2844@163.com (Z.W.); 201960370@ecut.edu.cn (Z.W.); syf541006935@126.com (Y.S.)

2 Nuclear Science and Technology Development Center, National Tsing Hua University, Hsinchu 300044, Taiwan; sctsai@mx.nthu.edu.tw

3 Xiamen Institute of Rare Earth Materials, Haixi Research Institute, Chinese Academy of Sciences, Xiamen 361021, China

4 Department of Nuclear Environmental Science, China Institute for Radiation Protection (CIRP), Taiyuan 030006, China

5 School of Political Science and Public Administration, Huaqiao University, Fujian 362021, China; helenyilingliu@hotmail.com

* Correspondence: nctien@mx.nthu.edu.tw (N.-C.T.); fanyang2013@fjirsm.ac.cn (F.Y.); Tel.: +86-18258244042 (N.-C.T.)

+ Chuan-Pin Lee and Yanqin Hu are equal contributions.

\begin{abstract}
An accurate and effective method combining ion chromatography (IC) and inductively coupled plasma optical emission spectrometry (ICP-OES) was applied in this work to qualitatively and quantitatively analyze individual and co-existing iodide $\left(\mathrm{I}^{-}\right)$and iodate $\left(\mathrm{IO}_{3}{ }^{-}\right)$at various concentrations. More specifically, a very strong linear relationship for the peak area for the co-existing $\mathrm{I}^{-}$and $\mathrm{IO}_{3}{ }^{-}$ions was reached, and a high resolution value between two peaks was observed, which proves the effectiveness of our combined IC-ICP-OES method at analyzing iodine species. We observed lower accessible porosity for the diffusion of both $\mathrm{I}^{-}$and $\mathrm{IO}_{3}{ }^{-}$in samples of bentonite clay using IC-ICP-OES detection methods, where the effective diffusion coefficient varied based on the anion exclusion effect and the size of the diffusing molecules. In fact, the distribution coefficients $\left(K_{d}\right)$ of both $\mathrm{I}^{-}$and $\mathrm{IO}_{3}{ }^{-}$were close to 0 , which indicates that there was no adsorption on bentonite clay. This finding can be explained by the fact that no change in speciation took place during the diffusion of $\mathrm{I}^{-}$and $\mathrm{IO}_{3}{ }^{-}$ions in bentonite clay. Our IC-ICP-OES method can be used to estimate the diffusion coefficients of various iodine species in natural environments.
\end{abstract}

Keywords: iodide $\left(\mathrm{I}^{-}\right)$; iodate $\left(\mathrm{IO}_{3}{ }^{-}\right)$; IC-ICPOES; bentonite; effective diffusion coefficient; accessible porosity; anion exclusion effect

\section{Introduction}

The design of a deep geological repository for spent fuel or high-level radioactive waste (HLW) generally adopts a "multi-barrier system". Generally, the underground facilities, waste containers, and buffer/backfill materials (e.g., bentonite clay) are known as engineering barriers, and the surrounding geological formations are known as natural barriers. In such a system, the engineering barriers and the geological medium serve a dual purpose: they ensure both the containment of the source term and the protection of the biosphere. In order to retard radionuclide release, the materials used in the construction of an HLW repository must have specific properties that help to prevent the dispersion of radioactivity. Such design parameters make it possible both to delay the time required for 
the radionuclides to reach the biosphere and to reduce their concentration by means of retarding mechanisms, including sorption, diffusion, and dispersion, so as to ensure the safety of the final disposal of radioactive waste $[1,2]$.

Bentonite clay is just such an engineering barrier that has often been used as a buffer/backfill material because of its retention effect on the migration of radionuclides to the biosphere [2,3]. Conducting performance assessments (PA) of Wyoming bentonite clay and other such materials in order to determine their physical and chemical properties has been a key element in the design of HLW repositories in the past 20 years. Studies have used experimental methods to identify the properties of bentonite, such as low hydraulic conductivity, good swelling and plasticity, low solute diffusivity, strong retardation of radionuclide migration, and high cation exchange capacity [4-8].

In addition to transuranic elements (TRU), the possible environmental impact of long-lived radionuclides that exhibit a relatively high mobility under certain geochemical conditions must be taken into consideration when designing an HLW repository. In particular, weakly adsorbed radionuclide anions are the most important, for example ${ }^{129} \mathrm{I},{ }^{99} \mathrm{Tc}$, and ${ }^{79} \mathrm{Se}[9-12]$. As one of the primary fission products, ${ }^{129} \mathrm{I}$ is characterized by a long half-life ( $t_{1 / 2}=1.57 \times 10^{7}$ years), a high fission yield, easy volatilization, easy migration, a high radioactive toxicity, and a high bioavailability. Furthermore, the $\mathrm{pH}$ of and the redox potential in aqueous solutions determines the form that iodine takes in the environment, including iodide $\left(\mathrm{I}^{-}\right)$, iodate $\left(\mathrm{IO}_{3}{ }^{-}\right), \mathrm{I}_{2}$, and organic iodine. Thus, ${ }^{129} \mathrm{I}$ is the main source of potential risk posed, not only by HLW repositories, but also by nuclear accidents such as the 2011 Fukushima Daiichi nuclear disaster. This threat has recently been made obvious when ${ }^{129}$ I was observed in the Pacific Ocean around Japan, where fast dispersion by the movement of the seawater and deposition caused it to migrate into the marine sediments [13].

While carrying out a safety assessment (SA) for the disposal of HLW, numerical models should be used in order to consider and evaluate a variety of scenarios, including the possibility of radionuclides being released into the environment and thus exposing people to radiation, as in the scenario in which radionuclides migrate into groundwater following the failure of the multi-barrier system after 10,000 years [14]. In fact, groundwater is the main carrier of migrating ${ }^{129} \mathrm{I}$, which can exist in various forms, of which $\mathrm{I}^{-}$and $\mathrm{IO}_{3}{ }^{-}$are the main anions found in groundwater $[15,16]$. Therefore, the diffusion behavior of $\mathrm{I}^{-}$and $\mathrm{IO}_{3}{ }^{-}$in the bentonite clay buffer is considered a major issue for the assessment of the possibility of the release of radionuclides into the environment from an HLW repository.

Several previous studies on fission products have been performed to calculate sorption and diffusion parameters, $K_{d}$ values, and diffusion coefficients under various conditions. For example, some research has recorded very low $K_{d}$ values $(\sim 0)[17,18]$. Another study in which through-diffusion experiments were performed with sand with bentonite clay mixtures obtained diffusion coefficients of ${ }^{125} \mathrm{I}^{-}: 5.1 \pm 0.8 \times 10^{-11} \mathrm{~m}^{2} \mathrm{~s}^{-1}$ [19]. Moreover, it has been suggested that the migration of iodine may be affected by its own physical and chemical properties, as in the case of the anion exclusion effect $[19,20]$. Finally, it is also possible that oxidation-reduction reactions occurring in the environment cause changes in the chemical form of iodine, thus also impacting its migration. However, few studies have focused on iodine speciation (e.g., $\mathrm{I}^{-}$and $\mathrm{IO}_{3}{ }^{-}$), on the one hand, because of the difficulty of separating the iodine from the environmental matrix and, on the other, because of the high cost of achieving accurate detection with a combination of advanced instrumental methods such as accelerator mass spectrometry (AMS), nanoscale secondary ion mass spectrometry (NanoSIMS), and inductively coupled plasma mass spectrometry (ICP-MS) [13,16,21,22].

In recent years, ion chromatography (IC) has become a popular and effective method applied to the analysis of anion speciation in environmental samples [16]. Another method used for quantifying anions based on deriving analytical solutions is inductively coupled plasma optical emission spectrometry (ICP-OES), a convenient and rapid tool with which the limit of detection can be determined. Therefore, in this paper, we propose a relatively 
simple, effective, and reliable method to detect $\mathrm{I}^{-}$and $\mathrm{IO}_{3}{ }^{-}$by combining IC and ICP-OES to create IC-ICP-OES. More specifically, we investigated the variability of the concentrations of $\mathrm{I}^{-}$and $\mathrm{IO}_{3}{ }^{-}$, both as individual ions and as co-existing ions, separating and analyzing them by calibrating the IC-ICP-OES to be able to carry out both qualitative and quantitative analyses. We also performed through-diffusion experiments to examine the diffusion behavior of $\mathrm{I}^{-}$and $\mathrm{IO}_{3}{ }^{-}$in compacted bentonite clay based on their diffusion coefficients. Our experiments with the IC-ICP-OES can serve as an important reference case while carrying out future SAs of engineering barriers used in HLW repositories in China.

\section{Materials and Methods}

\subsection{Characterization of Bentonite Clay}

The material tested in this work was a sample of Wyoming Na-bentonite clay purchased from American Colloid Company. It had a montmorillonite content of approximately $85-90 \mathrm{wt} . \%$. Previous studies have investigated its mineralogical and chemical properties using $\mathrm{X}$-ray diffraction analysis techniques to identify several minor mineral components such as quartz and feldspar [23,24]. In this study, a wavelength dispersive Xray fluorescence (WDXRF) spectrometer (Axios, PANalytical Inc., Amsterdam, the Netherlands) was employed to analyze samples of commercial bentonite clay from Wyoming (B) and Taiwan (Z), as well as a sample of standard montmorillonite from Inner Mongolia in China (M). The chemical compositions of these clays are given in Table 1. These results were compared for reference.

Table 1. The chemical properties of commercial bentonite clay from three sources.

\begin{tabular}{cccc}
\hline Element (\%) & Wyoming & Taiwan & Inner Mongolia \\
\hline $\mathrm{SiO}_{2}$ & 53.78 & 50.87 & 63.71 \\
$\mathrm{Al}_{2} \mathrm{O}_{3}$ & 17.59 & 15.54 & 13.44 \\
$\mathrm{Fe}_{2} \mathrm{O}_{3}$ & 3.24 & 5.93 & 2.01 \\
$\mathrm{CaO}$ & 1.29 & 2.83 & 0.90 \\
$\mathrm{Na} 2$ & 1.92 & 1.21 & 1.67 \\
$\mathrm{~K}_{2} \mathrm{O}$ & 0.47 & 1.41 & 0.67 \\
$\mathrm{MnO}$ & 0.01 & 0.10 & 0.04 \\
$\mathrm{MgO}$ & 2.04 & 2.11 & 2.67 \\
$\mathrm{TiO}_{2}$ & 0.14 & 0.38 & 0.12 \\
$\mathrm{P}_{2} \mathrm{O}_{5}$ & 0.05 & 0.07 & 0.03 \\
$*$ & 16.77 & 12.72 & 12.91 \\
\hline
\end{tabular}

${ }^{*}$ LOI: Loss On Ignition.

\subsection{Preparation of Iodide $\left(\mathrm{I}^{-}\right)$and Iodate $\left(\mathrm{IO}_{3}^{-}\right)$Standard Solution}

All chemical reagents used in our experiments were of analytical grade of purity, and the Milli- $\mathrm{Q}^{\circledR}$ ultrapure water has a resistivity of $18.2 \mathrm{M} \Omega . \mathrm{cm}$ (Merck, Darmstadt, Germany). A standardized potassium iodide (KI) solution containing $1.20 \pm 0.05 \mathrm{~g}$ of KI and a potassium iodate $\left(\mathrm{KIO}_{3}\right)$ solution containing $1.30 \pm 0.05 \mathrm{~g}$ of $\mathrm{KIO}_{3}$ were prepared in deionized water and $3-5 \%$ of nitric acid $\left(\mathrm{HNO}_{3}\right)$. Finally, these solutions were diluted 100 times with deionized water to $1 \mathrm{~L}$ in a volumetric flask. The concentrations of $\mathrm{I}^{-}$ and $\mathrm{IO}_{3}{ }^{-}$in the diluted solutions were measured and analyzed by means of IC and ICP-OES (iCAP 7000, Thermo Fisher Scientific Inc., Waltham, MA, USA) to the point at which the variation of element concentrations was within $5 \%$ of the corresponding liquid phase concentrations.

\subsection{Qualitative and Quantitative Analyses with IC-ICP-OES to Detect $\mathrm{I}^{-}$and $\mathrm{IO}_{3}{ }^{-}$}

We used an IC instrument equipped with a conductivity detector to analyze the different iodine species, and then we quantitatively measured them with ICP-OES. By deriving an analytical solution, the $\mathrm{I}^{-}$and $\mathrm{IO}_{3}{ }^{-}$anions could be effectively detected and separated through the combination of IC and ICP-OES techniques. In addition, an ICS600 system (Thermo Fisher Scientific Inc., Waltham, MA, USA) was equipped with 
a gradient pump, an injection valve with a $10 \mu \mathrm{L}$ sample loop, and an anion-exchange column ( $250 \mathrm{~mm} \times 4.6 \mathrm{~mm}$ inner diameter). Moreover, the eluent solution used in the IC procedure consisted of $1.0 \mathrm{mM} \mathrm{NaHCO}_{3}$ and $3.2 \mathrm{mM} \mathrm{Na}_{2} \mathrm{CO}_{3}$, with degassing performed with a DG-2410 degasser (Uniflows, Tokyo, Japan) before the injection of individual and co-existing $\mathrm{I}^{-}$and $\mathrm{IO}_{3}{ }^{-}$ions. Finally, the resolution (R) was calculated based on the peak areas and retention times:

$$
\mathrm{R}=0.5 \times\left(\mathrm{M}_{1}+\mathrm{M}_{2}\right) /\left(\mathrm{M}_{1}-\mathrm{M}_{2}\right) \times(\mathrm{s} / \mathrm{a})
$$

where $\mathrm{M}_{1}$ and $\mathrm{M}_{2}$ represent the peak areas of $\mathrm{I}^{-}$and $\mathrm{IO}_{3}{ }^{-}$, respectively; $\mathrm{a}$ is the peak width at $5 \%$ of the peak height (for $\mathrm{I}^{-}$and $\mathrm{IO}_{3}{ }^{-}$); and $\mathrm{s}$ is the time difference between the peak heights of $\mathrm{I}^{-}$and $\mathrm{IO}_{3}{ }^{-}$. The results showed that two peaks could be effectively separated and identified at $\mathrm{R}>0.5$.

\subsection{Through-Diffusion Experiments (TD): Column Tests}

We developed and verified a precise and reliable apparatus with sandwich-like columns to conduct through-diffusion (TD) experiments, as shown in Figure 1. A similar experimental apparatus has been employed in several past studies [12,20,25]. The MX-80 bentonite sample dimension in thickness and cross-sectional area was $3 \mathrm{~mm}$ and $19.6 \mathrm{~cm}^{2}$, respectively. The sample slab was inserted and fixed in a holder and was sandwiched between two glass microfiber filters ( $0.4 \mathrm{~mm}$ thickness) with pore size of $0.7 \mathrm{um}$ (GF/F, Associated Design \& Manufacturing Co., Alexandria, VA, USA), a Teflon O-ring, and constrainers. Figure 1 shows a schematic description of the diffusion cell for compacted bentonite in the through-diffusion experiments. The Teflon O-ring and constrainers were used to reduce cell deformation, minimize diffusion resistance, and resist swelling pressure induced by the bentonite clay following saturation with water. The previous literature reported that concentration gradient between inlet and outlet diffusion cells with filters has few differences in estimating effective diffusion coefficients of $\mathrm{HTO},{ }^{125} \mathrm{I}^{-}$and ${ }^{134} \mathrm{Cs}^{+}$[19].

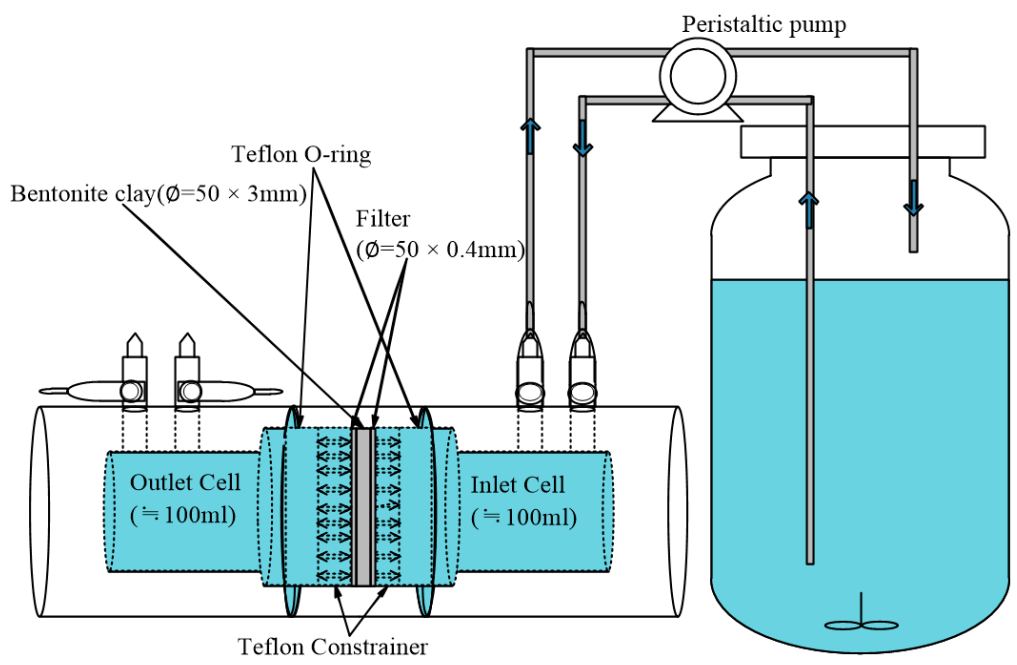

Figure 1. The TD apparatus with a sandwich-like column.

The setup consisted mainly of a highly precise multichannel isocratic peristaltic pump (Masterflex L/S, Cole-Parmer Instrument Co., Barrington, IL, USA) for use with two polypropylene (PP) columns (No. 1-2, modified type, Hsinchu ZeGi Industrial Co., Ltd., Hsinchu, Taiwan), an initial tracer reservoir containing individual $\mathrm{I}^{-}\left(\mathrm{C}_{0}=1000 \pm 50 \mathrm{ppm}\right)$ and $\mathrm{IO}_{3}{ }^{-}\left(\mathrm{C}_{0}=1000 \pm 50 \mathrm{ppm}\right)$ ions, and various Teflon ${ }^{\circledR}$ (PTFE) units and connectors. The PP columns were made of pressure-resistant polypropylene ( $<10 \mathrm{MPa})$ and had a length of $13.6 \mathrm{~cm}$ and an inner diameter of $5 \mathrm{~cm}$. They were filled with bentonite clay having a total porosity of 0.26 and a bulk density of $2.0 \mathrm{~g} / \mathrm{cm}^{3}$. 


\subsection{Estimation of Diffusion Coefficient}

In this work, Fick's second law was applied to estimate the diffusion coefficients $(D)$ for $\mathrm{I}^{-}$and $\mathrm{IO}_{3}{ }^{-}$in compacted bentonite clay. The one-dimensional diffusion equation for the radionuclides can be written as follows:

$$
\frac{\partial C}{\partial t}=\frac{D_{e}}{\alpha} \frac{\partial^{2} C}{\partial x^{2}},\left(D_{a}=\frac{D_{e}}{\alpha}, \alpha=\theta+\rho_{b} K_{d}\right)
$$

where $D_{e}$ and $D_{a}$ are the effective and apparent diffusion coefficients, respectively; $\alpha$ (capacity factor) is a function of the bulk density of the dry material $\left(\rho_{b}\right)$, the total porosity of compacted samples $(\theta)$, and the distribution coefficient $K_{d}$; and $C$ is the concentration of the solute in the liquid phase. The rate at which molecules spread determines the diffusion coefficient $(D)$, which is the proportionality constant between the mass flux and the concentration gradient of the solute. Both boundary and initial conditions limit the through-diffusion experimental method and can be expressed as follows:

$$
\begin{gathered}
C(x, 0)=0,0<x<L \\
C(0, t)=C_{0} \\
C(L, t) \sim 0
\end{gathered}
$$

where the tracer concentration in the reservoir containing the tracer is constant $\left(C_{0}\right)$; the ion concentration in the opposing reservoir is kept close to zero; and $L$ is the overall duration of the compaction of the clay samples.

As defined by Crank [26], the cumulative mass, $M$, and the concentration ratio, $C R(t)$, of $\mathrm{I}^{-}$and $\mathrm{IO}_{3}{ }^{-}$in the measurement reservoir were calculated according to the following formula:

$$
\mathrm{CR}(\mathrm{t})=\frac{\sum C(t)}{C_{0}}=\frac{L S}{V}\left(\frac{D_{e} t}{L^{2}}-\frac{\alpha}{6}-\frac{2}{\pi^{2}} \sum_{n=1}^{\infty} \frac{(-1)^{n}}{n^{2}} \exp \left[\frac{-n^{2} \pi^{2} D_{e} t}{L^{2}}\right]\right)
$$

where $D_{e}$ is the effective diffusion coefficient that takes the capacity factor $(\alpha)$ into consideration and $\mathrm{V}$ and $\mathrm{S}$ are the diffusion volume and the cross-section area of the compacted samples, respectively. When sufficient time is allowed to carry out the TD test, the diffusion process reaches a steady state. Consequently, the exponential term in Equation (3) tends to zero, and the profile curve illustrating the distribution of the $\mathrm{CR}(\mathrm{t})$ shows a linear relationship with time $(t)$. Moreover, using a method for statistical data analysis that had previously been developed [25], we compared our measurements for $\mathrm{I}^{-}$and $\mathrm{IO}_{3}{ }^{-}$and evaluated them in terms of the steady-state diffusion condition and its relation to time. The combination of the IC and ICP-OES techniques makes it possible to determine whether or not the speciation of $\mathrm{I}^{-}$and $\mathrm{IO}_{3}{ }^{-}$changes during the diffusion process. Therefore, using both techniques while concurrently performing experimental and numerical analyses of $\mathrm{I}^{-}$and $\mathrm{IO}_{3}{ }^{-}$provides an effective and important tool for carrying out future safety assessments of HLW repositories.

\subsection{Estimation of Distribution Coefficients $\left(K_{d}\right)$}

We performed a simulation of batch sorption experiments with $\mathrm{I}^{-}$and $\mathrm{IO}_{3}{ }^{-}$in bentonite clay. More specifically, the standard ASTM batch method [27] was applied to three solutions of $50 \mathrm{~mL}$, each containing samples of bentonite prepared in centrifuge tubes. Thus, the adsorption of $\mathrm{I}^{-}$and $\mathrm{IO}_{3}{ }^{-}$in the bentonite was observed by measuring the $\mathrm{pH}$, Eh, and the final ion concentrations. In order to introduce stable isotope tracers, an individual $\mathrm{I}^{-}$and $\mathrm{IO}_{3}{ }^{-}$stock solution was added to the initial bentonite solution prior to the batch testing. The $\mathrm{I}^{-}$and $\mathrm{IO}_{3}{ }^{-}$stock solution was prepared at initial concentrations $\left(C_{0}\right)$ of 5,10 , and $20 \mathrm{ppm}$. All batch tests were conducted on solutions with a solid-liquid ratio of $1 \mathrm{~g}$ per $30 \mathrm{~mL}$. The centrifuge tubes were placed in an oscillating thermostatic shaker, and the solutions were uniformly mixed at $200 \mathrm{rpm}$ for 7 days. The solid and liquid phases were separated by being put in a high-speed centrifuge $(R C F=10,000 \mathrm{~g})$ for $30 \mathrm{~min}$. 
Approximately $10 \mathrm{~mL}$ of the supernatant was reserved to analyze the final concentrations of the $\mathrm{I}^{-}$and $\mathrm{IO}_{3}{ }^{-}$by means of a combination of the IC and off-line ICP-OES techniques, at which time changes in $\mathrm{pH}$ and $\mathrm{Eh}$ were also recorded. As a result, the distribution coefficient $\left(K_{d}\right)$ for $\mathrm{I}^{-}$and $\mathrm{IO}_{3}{ }^{-}$can be written as follows:

$$
K_{d}=\frac{C_{0}-C}{C} \frac{V}{m}
$$

where $C_{0}$ is the initial ion concentration of $\mathrm{I}^{-}\left({\mathrm{or} \mathrm{IO}_{3}}^{-}\right)$; $\mathrm{C}$ is the final ion concentration; and $\mathrm{V}$ and $\mathrm{m}$ are the volume $(\mathrm{mL})$ and mass $(\mathrm{g})$ of the samples, respectively.

\section{Results}

\subsection{Identification for Individual $\mathrm{I}^{-}$and $\mathrm{IO}_{3}{ }^{-}$}

Solutions $(10 \mu \mathrm{L})$ containing various concentrations of $\mathrm{I}^{-}$and $\mathrm{IO}_{3}{ }^{-}$ions were injected into an IC system, with measurements simultaneously taken by a conductivity detector and ICP-OES equipment and elution performed with a solution of $1.0 \mathrm{mM} \mathrm{NaHCO}_{3}$ and $3.2 \mathrm{mM}$ $\mathrm{Na}_{2} \mathrm{CO}_{3}$ (See results in Table 2). After diluting the solutions 100-500 times, distinct peaks at $20 \mathrm{~min}$ and $4 \mathrm{~min}$ on the chromatograms for the individual $\mathrm{I}^{-}$and $\mathrm{IO}_{3}{ }^{-}$, respectively, with a very clear peak for $\mathrm{IO}_{3}{ }^{-}$, show that these ions were effectively separated and detected by IC in the range 100-500 ppm (See Figure 2). This finding also demonstrates that ICP-OES was able to identify the $\mathrm{I}^{-}$and $\mathrm{IO}_{3}{ }^{-}$ions as forms of iodine after linear calibration had been performed. However, conductivity peaks were much less prominent at the concentration of $100 \mathrm{ppm}$, which made it very difficult to distinguish $\mathrm{I}^{-}$and $\mathrm{IO}_{3}{ }^{-}$.

Table 2. The characteristics of the individual $\mathrm{I}^{-}$and $\mathrm{IO}_{3}{ }^{-}$in different concentration.

\begin{tabular}{|c|c|c|c|}
\hline Iodine Speciation & No. & $C(p p m)$ & Area $(\mathrm{uS} / \mathrm{cm} \cdot \mathrm{s})$ \\
\hline & 1 & 140 & 372.2 \\
\hline $\mathrm{I}^{-}$ & 2 & 220 & 602.5 \\
\hline (Retention time: $\sim 20 \mathrm{~min}$ ) & 3 & 360 & 1060.1 \\
\hline & 4 & 550 & 1677.1 \\
\hline${ }^{*} \mathrm{R}^{2}$ & \multicolumn{3}{|c|}{0.99} \\
\hline \multirow{4}{*}{$\begin{array}{c}\mathrm{IO}_{3}^{-} \\
\text {(Retention time: } \sim 4 \mathrm{~min} \text { ) }\end{array}$} & 5 & 170 & 261.7 \\
\hline & 6 & 260 & 503.0 \\
\hline & 7 & 430 & 859.0 \\
\hline & 8 & 650 & 1372.0 \\
\hline$* R^{2}$ & \multicolumn{3}{|c|}{0.99} \\
\hline
\end{tabular}

${ }^{*} R^{2}$ : R-squares.

\subsection{Performance for $\mathrm{Co}$-Existing $\mathrm{I}^{-}$and $\mathrm{IO}_{3}{ }^{-}$}

IC was also used to analyze solutions with different concentrations of co-existing I ${ }^{-}$ and $\mathrm{IO}_{3}{ }^{-}$ions (Table 3 and Figure 3). The resulting chromatograms are in agreement with those shown in Figure 2 in terms of individual peak height, peak area, and retention time. Moreover, a very strong linear relationship for the peak area for the co-existing $\mathrm{I}^{-}$and $\mathrm{IO}_{3}{ }^{-}$ ions was reached (0.99), and a high resolution value (R: 52.30 79.36) between two peaks was observed, which proves that IC provided a very effective qualitative and quantitative analysis of the two forms of iodine investigated in this study. 


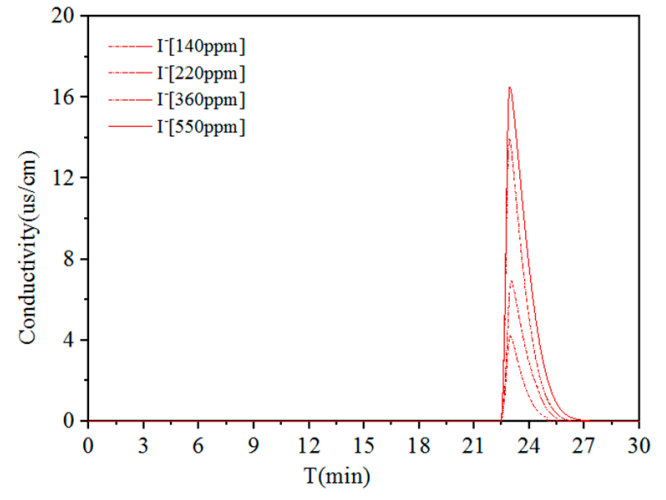

(a)

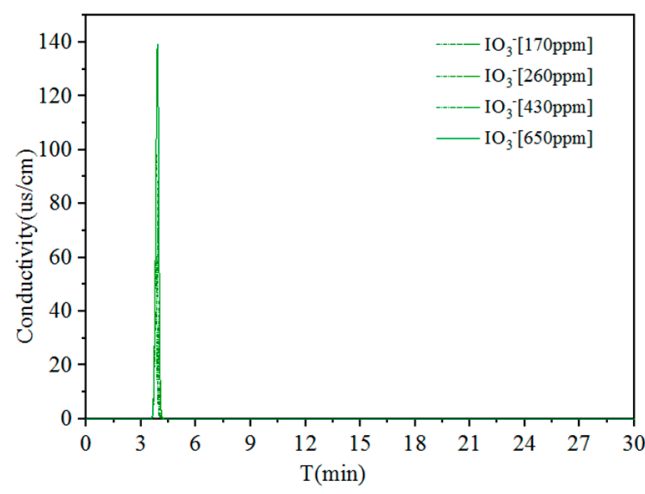

(b)

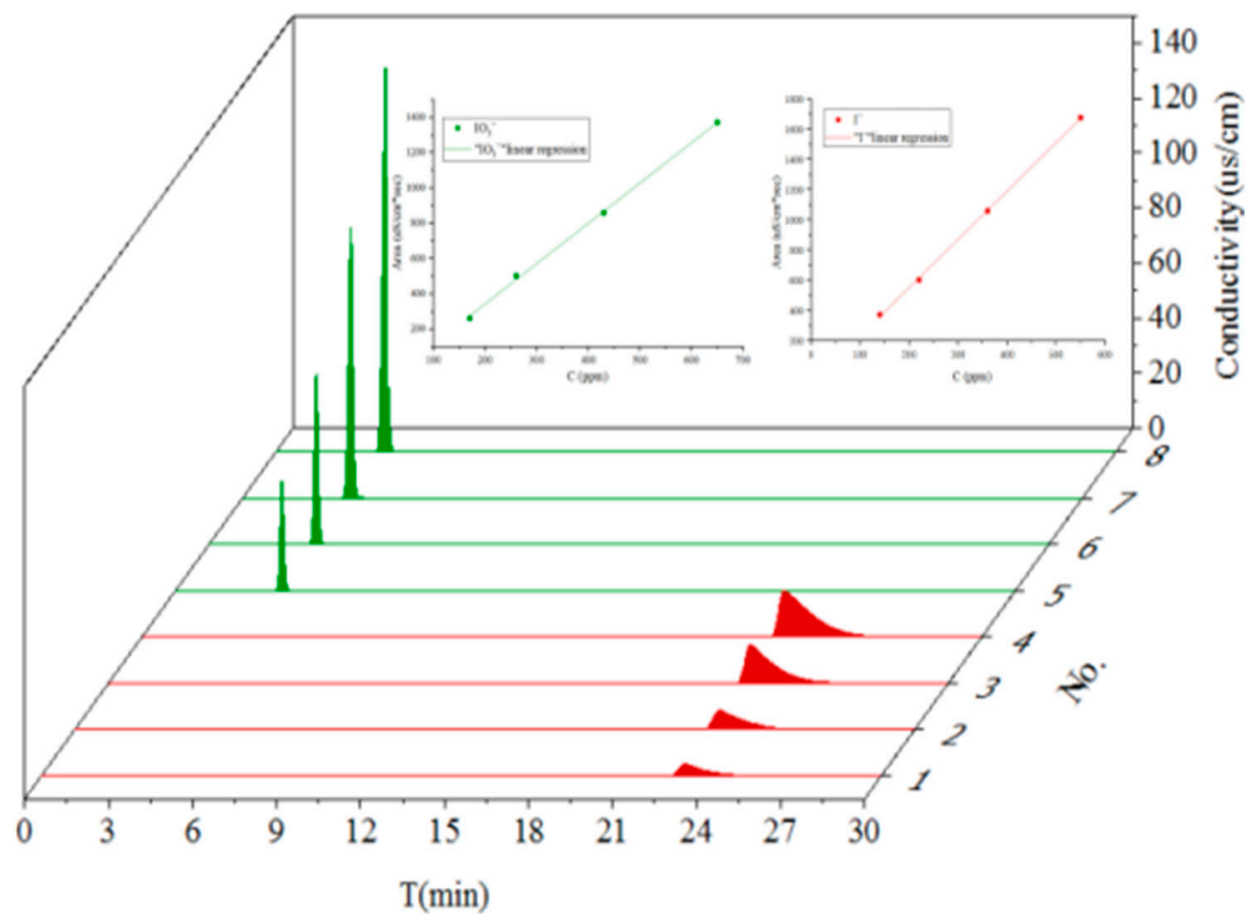

(c)

Figure 2. The chromatographic peaks for individual $\mathrm{I}^{-}$and $\mathrm{IO}_{3}{ }^{-}$at different concentrations. (a) $\mathrm{I}^{-}$; (b) $\mathrm{IO}_{3}{ }^{-}$; (c) the linear relationship between peak area and concentration of $\mathrm{I}^{-}$and $\mathrm{IO}_{3}{ }^{-}$.

Table 3. The characteristics of the co-existing $\mathrm{I}^{-}$and $\mathrm{IO}_{3}{ }^{-}$at different concentration.

\begin{tabular}{|c|c|c|c|c|c|c|}
\hline No. & Item & $\begin{array}{c}\mathbf{I}^{-} \\
(\mathrm{ppm})\end{array}$ & $\begin{array}{c}\text { Area } \\
(\mathrm{uS} / \mathrm{cm} \cdot \mathrm{s})\end{array}$ & $\begin{array}{l}\mathrm{IO}_{3}^{-} \\
(\mathrm{ppm})\end{array}$ & $\begin{array}{c}\text { Area } \\
(\mathrm{uS} / \mathrm{cm} \cdot \mathrm{s})\end{array}$ & ${ }^{*} \mathbf{R}$ \\
\hline & 1 & 104 & 192.60 & 67 & 166.14 & 79.36 \\
\hline & 2 & 137 & 266.94 & 102 & 273.76 & 68.67 \\
\hline & 3 & 212 & 436.76 & 173 & 518.48 & 52.30 \\
\hline & 4 & 382 & 921.08 & 267 & 781.06 & 71.17 \\
\hline & 5 & 742 & 1631.97 & 554 & 1667.85 & 69.19 \\
\hline & $* * \mathrm{R}^{2}$ & \multicolumn{2}{|c|}{0.99} & \multicolumn{2}{|c|}{0.99} & - \\
\hline
\end{tabular}

${ }^{*} \mathrm{R}$ (resolution value); ${ }^{* *} \mathrm{R}^{2}$ (linear regression coefficient). 


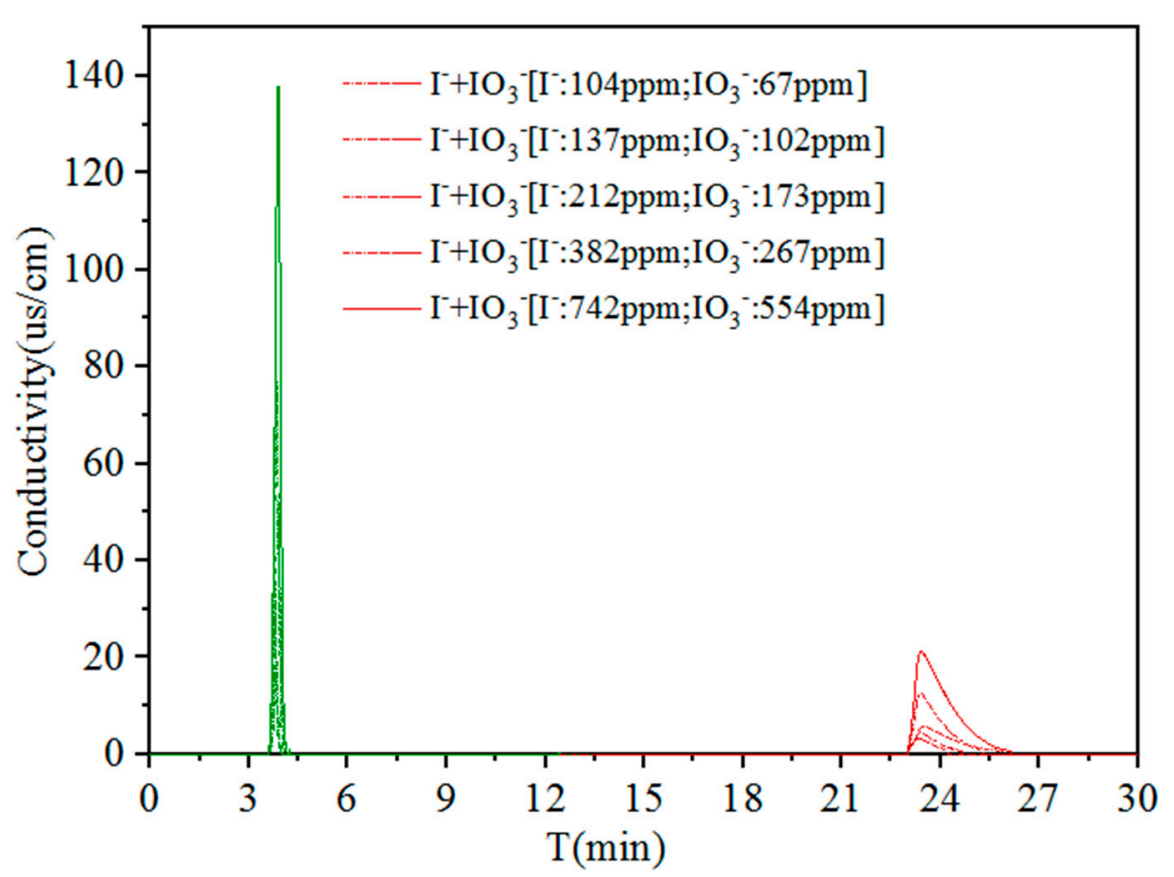

(a)

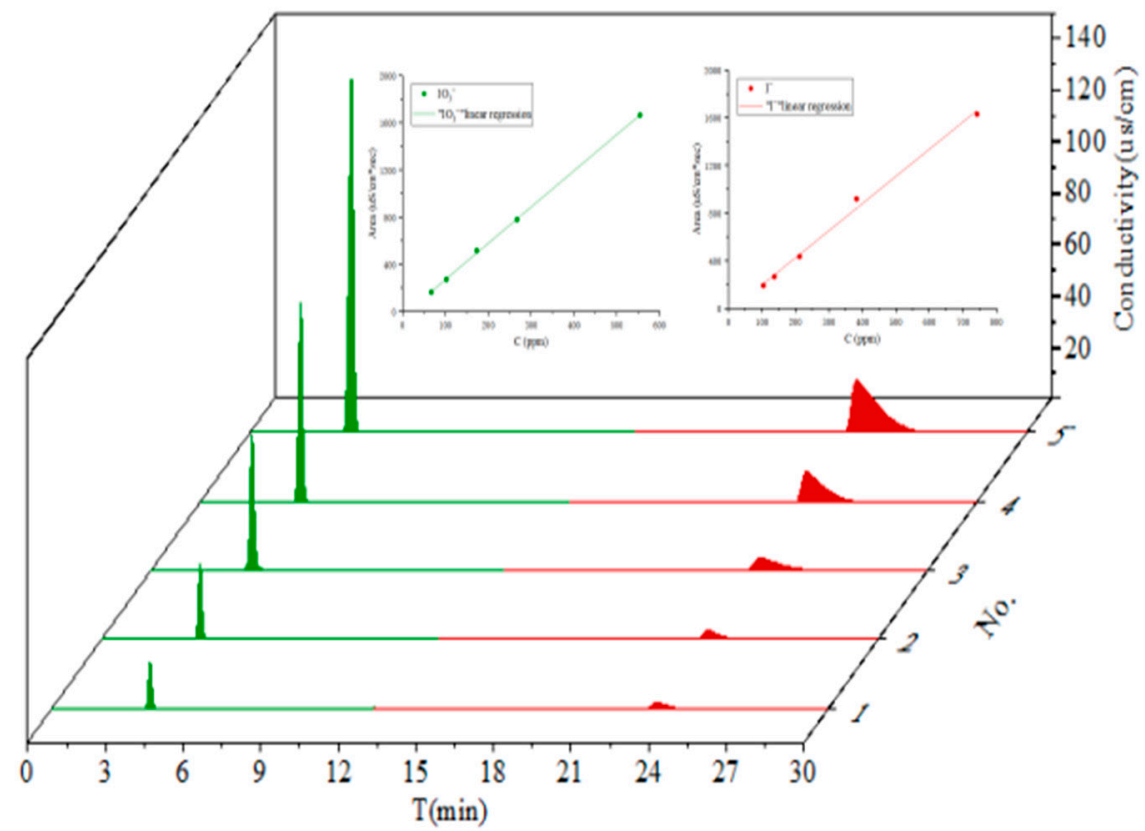

(b)

Figure 3. The chromatographical peak for co-existing $\mathrm{I}^{-}$and $\mathrm{IO}_{3}{ }^{-}$at different concentration. (a) $\mathrm{I}^{-}$ (green line) and $\mathrm{IO}_{3}^{-}$(red line) same in Figure 2; (b) the linear relationship between peak area and concentration of co-existing $\mathrm{I}^{-}$and $\mathrm{IO}_{3}{ }^{-}$.

\subsection{Diffusion of $\mathrm{I}^{-}$and $\mathrm{IO}_{3}^{-}$}

The results of the TD experiments with our IC-ICP-OES method indicate that the time required for the $\mathrm{I}^{-}$and $\mathrm{IO}_{3}{ }^{-}$ions to diffuse out of the bentonite clay was approximately $24 \mathrm{~h}$, with the steady-state condition reached in 7 to 10 days as a result of a constant diffusion flux. The effective diffusion coefficient $\left(D_{e}\right)$ and the capacity factor $(\alpha)$ for the $\mathrm{I}^{-}$ and $\mathrm{IO}_{3}{ }^{-}$ions in compacted bentonite were estimated on the basis of numerical analyses, including calculating graphical asymptotes, finding analytical solutions with Lsqcurvefit, and modeling with dual period diffusion model (DPDM) [25,28] (See Table 4 and Figure 4). 
Our findings indicate that the diffusion of the $\mathrm{I}^{-}$and $\mathrm{IO}_{3}{ }^{-}$ions in bentonite clay could be suitable fitting, which can be explained by the fact that no change in speciation was detected by means of the IC-ICP-OES technique.

Table 4. The diffusion characteristics of different radionuclides in compacted Wyoming bentonite.

\begin{tabular}{ccccc}
\hline $\mathbf{R N}$ & $\rho_{\boldsymbol{b}}\left(\mathrm{g} / \mathbf{c m}^{3}\right)$ & $\boldsymbol{D}_{\boldsymbol{e}}\left(\mathbf{m}^{2} / \mathbf{s}\right)$ & $\alpha_{\text {acc }}$ & Reference \\
\hline $\mathrm{I}^{-}$ & 2.0 & $3.28 \times 10^{-11}$ & 0.20 & In this work \\
$\mathrm{IO}_{3}{ }^{-}$ & 2.0 & $2.43 \times 10^{-11}$ & 0.25 & In this work \\
${ }^{99} \mathrm{TcO}_{4}{ }^{-}$ & 2.0 & $4.38 \times 10^{-13}$ & 0.06 & Lee, C.P. et al. 2021 [25] \\
& 1.2 & $8.89 \times 10^{-12}$ & 0.39 & Lee, C.P. et al. 2021 [25] \\
$\mathrm{HTO}$ & 2.0 & $2.16 \times 10^{-11}$ & 0.29 & Lee, C.P. et al. 2021 [25] \\
$\mathrm{SeO}_{3}{ }^{2-}(\mathrm{IV})$ & 1.2 & $6.25 \times 10^{-11}$ & 0.56 & Lee, C.P. et al. 2021 [25] \\
\hline
\end{tabular}

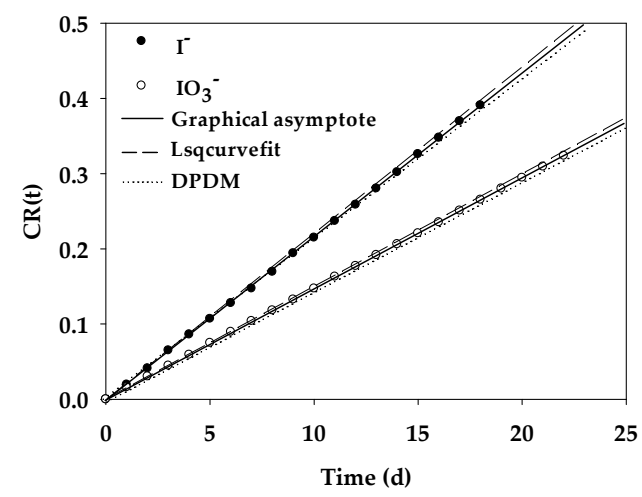

(a)

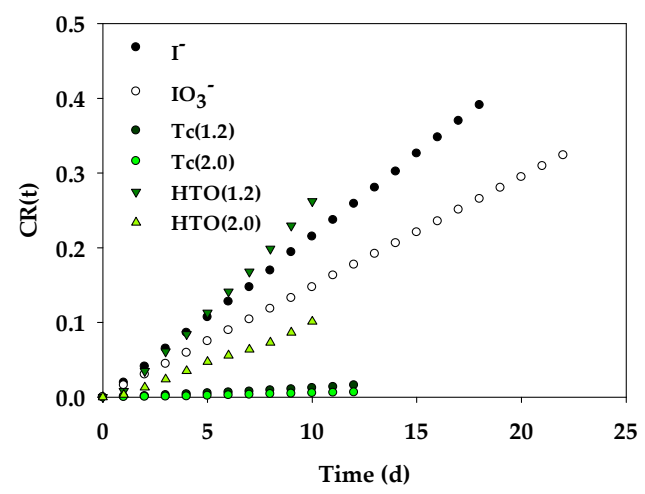

(b)

Figure 4. The diffusion curves of $\mathrm{I}^{-}$and $\mathrm{IO}_{3}{ }^{-}$in bentonite clay. (a) $\mathrm{I}^{-}$and $\mathrm{IO}_{3}{ }^{-} ;(\mathbf{b})$ other radionuclides.

\subsection{Batch Tests of $\mathrm{I}^{-}$and $\mathrm{IO}_{3}{ }^{-}$}

The batch experiments conducted with the IC-ICP-OES method indicated that the adsorption of $\mathrm{I}^{-}$and $\mathrm{IO}_{3}{ }^{-}$in three samples of bentonite clay reached the steady-state condition in approximately 7 days. Table 5 lists the individual values of the $\mathrm{pH}, \mathrm{Eh}$, and distribution coefficients $\left(K_{d}\right)$ for the $\mathrm{I}^{-}$and $\mathrm{IO}_{3}{ }^{-}$ions in compacted bentonite. Our findings indicate that no sorption of $\mathrm{I}^{-}$and $\mathrm{IO}_{3}{ }^{-}$has taken place in the bentonite clay samples, which can be explained by the fact that no change in speciation was detected by means of the IC-ICP-OES technique.

Table 5. The $\mathrm{pH}$, Eh, and distribution coefficients $\left(K_{d}\right)$ for $\mathrm{I}^{-}$and $\mathrm{IO}_{3}{ }^{-}$in three samples of bentonite clay.

\begin{tabular}{|c|c|c|c|c|c|c|c|c|c|c|}
\hline \multirow{2}{*}{ RN } & \multirow{2}{*}{$\begin{array}{c}\mathrm{C}_{0} \\
(\mathrm{ppm})\end{array}$} & \multicolumn{3}{|c|}{ Wyoming } & \multicolumn{3}{|c|}{ Taiwan } & \multicolumn{3}{|c|}{ Inner Mongolia } \\
\hline & & $\mathrm{pH}$ & Eh $(\mathrm{mV})$ & $K_{d}(\mathrm{~mL} / \mathrm{g})$ & $\mathrm{pH}$ & Eh $(\mathrm{mV})$ & $K_{d}(\mathrm{~mL} / \mathrm{g})$ & $\mathrm{pH}$ & Eh $(\mathrm{mV})$ & $K_{d}(\mathrm{~mL} / \mathrm{g})$ \\
\hline $\mathrm{I}^{-}$ & $\begin{array}{c}5 \\
10 \\
20\end{array}$ & $\begin{array}{l}9.46 \pm 0.13 \\
9.55 \pm 0.07 \\
9.57 \pm 0.06\end{array}$ & $\begin{array}{l}251 \pm 6 \\
116 \pm 5 \\
241 \pm 2\end{array}$ & $\begin{array}{c}0.01 \pm 0.00 \\
\sim 0 \\
\sim 0\end{array}$ & $\begin{array}{l}7.23 \pm 0.08 \\
7.94 \pm 0.45 \\
8.53 \pm 0.04\end{array}$ & $\begin{array}{l}170 \pm 1 \\
282 \pm 7 \\
306 \pm 4\end{array}$ & $\begin{array}{c}\sim 0 \\
0.03 \pm 0.00 \\
\sim 0\end{array}$ & $\begin{array}{l}9.22 \pm 0.03 \\
9.05 \pm 0.27 \\
9.11 \pm 0.16\end{array}$ & $\begin{array}{c}221 \pm 3 \\
186 \pm 15 \\
211 \pm 8\end{array}$ & $\begin{array}{c}0.01 \pm 0.00 \\
\sim 0 \\
\sim 0\end{array}$ \\
\hline $\mathrm{IO}_{3}^{-}$ & $\begin{array}{c}20 \\
5 \\
10 \\
20\end{array}$ & $\begin{array}{l}9.53 \pm 0.04 \\
9.26 \pm 0.33 \\
9.38 \pm 0.02\end{array}$ & $\begin{array}{l}243 \pm 9 \\
243 \pm 8 \\
187 \pm 9\end{array}$ & $\begin{array}{c}\sim 0 \\
0.01 \stackrel{\sim 0}{\sim} 0.00 \\
\sim 0\end{array}$ & $\begin{array}{l}8.24 \pm 0.01 \\
8.05 \pm 0.02 \\
8.07 \pm 0.11\end{array}$ & $\begin{array}{c}321 \pm 9 \\
247 \pm 17 \\
225 \pm 3\end{array}$ & $\begin{array}{c}0.02 \pm 0.00 \\
0.01 \pm 0.00 \\
\sim 0\end{array}$ & $\begin{array}{l}9.13 \pm 0.14 \\
9.36 \pm 0.03 \\
9.28 \pm 0.22\end{array}$ & $\begin{array}{c}273 \pm 8 \\
233 \pm 12 \\
197 \pm 4\end{array}$ & $\begin{array}{c}0.01 \pm 0.00 \\
0.01 \pm 0.00 \\
\sim 0\end{array}$ \\
\hline
\end{tabular}

\section{Discussion}

In this work, individual $\mathrm{IO}_{3}{ }^{-}$ions were consistently detected first, after which individual $\mathrm{I}^{-}$was extracted by elution from the solution containing co-existing $\mathrm{I}^{-}$and $\mathrm{IO}_{3}{ }^{-}$ ions. Generally, the affinity of the anion exchange resin is quite different for $\mathrm{I}^{-}$and $\mathrm{IO}_{3}{ }^{-}$, with $\mathrm{I}^{-}$being subject to a higher adsorption affinity and anion exchange and showing a slower retention time $(\sim 20 \mathrm{~min})$ than $\mathrm{IO}_{3}{ }^{-}(\sim 4 \mathrm{~min})$ during the elution process. In fact, it has been shown that some ions interfere with the IC-based detection of $\mathrm{I}^{-}$and $\mathrm{IO}_{3}{ }^{-}$ions in 
complex and natural environments [16,29], a problem that could be solved by combining IC with such instruments as ICP-MS, AMS, or other instruments for measuring radioactivity. To this end, we have developed a more effective and accurate technique based on the combination of the IC and the ICP-OES methods to analyze qualitatively and quantitatively both individual and co-existing $\mathrm{I}^{-}$and $\mathrm{IO}_{3}{ }^{-}$ions in solutions at various concentrations.

In this study, tritiated water $\left({ }^{3} \mathrm{H}_{2} \mathrm{O}\right)$, a non-reactive radiotracer, was used to estimate the total porosity ( $\theta=$ the ratio of pore volume to total volume) of the bentonite clay. Because the total porosity is equivalent to the water content, ${ }^{3} \mathrm{H}_{2} \mathrm{O}$ is commonly applied to the identification of all chemical elements that are not retained in the solid phase. We showed that the porosity accessible $\left(\alpha_{\mathrm{acc}}\right)$ to both $\mathrm{I}^{-}$and $\mathrm{IO}_{3}{ }^{-}$ions was lower than that accessible to HTO, which was determined on the basis of the anion exclusion effect $\left(K_{d} \sim 0\right)[20,25]$ and the decreasing number of interlayer pores $[10,30,31]$. This result indicates that $\mathrm{I}^{-}$and $\mathrm{IO}_{3}{ }^{-}$ ions have a similar mobility as does ${ }^{3} \mathrm{H}_{2} \mathrm{O}$ when the effective diffusion coefficients (De) are compared. Moreover, there were significant differences between the anions present in bentonite clay with regards to the exclusion effect, which has been associated with the size or hydrated radius of $\mathrm{I}^{-}(\sim 2.16 \AA), \mathrm{IO}_{3}{ }^{-}(\sim 3.30 \AA)$, and ${ }^{99} \mathrm{TcO}_{4}{ }^{-}(\sim 3.50 \AA)$ [32,33]. On the other hand, the porosity accessible $\left(\alpha_{\mathrm{acc}}\right)$ to $\mathrm{SeO}_{3}{ }^{2-}$ (IV) might be higher than that accessible to ${ }^{3} \mathrm{H}_{2} \mathrm{O}$ as a result of the anion exclusion effect and the weak adsorption effect $\left(K_{d}>0\right)$ [20]. The parameters of these different anions are listed in Table 4; the $\mathrm{I}^{-}$and $\mathrm{IO}_{3}{ }^{-}$anions were investigated in this paper and the ${ }^{99} \mathrm{TcO}_{4}{ }^{-}$and $\mathrm{SeO}_{3}{ }^{2-}$ (IV) anions were examined in previous research $[20,25]$.

\section{Conclusions}

In this paper, we developed a relatively simple, effective, and reliable method to detect individual and co-existing $\mathrm{I}^{-}$and $\mathrm{IO}_{3}{ }^{-}$ions through a combination of ion chromatography (IC) and inductively coupled plasma optical emission spectrometry (ICP-OES) techniques, which we call IC-ICP-OES. The anion exchange resin exhibited a different affinity for $\mathrm{I}^{-}$and $\mathrm{IO}_{3}{ }^{-}$, with $\mathrm{I}^{-}$being subject to a higher adsorption affinity and anion exchange. This finding demonstrates that ICP-OES was able to identify the $\mathrm{I}^{-}$and $\mathrm{IO}_{3}{ }^{-}$ions as forms of iodine after linear calibration had been performed. In fact, there was obvious interference with the performance of the conductivity detector during the IC-based $\mathrm{I}^{-}$and $\mathrm{IO}_{3}{ }^{-}$analysis procedure, which suggested the possibility of combining IC with an offline ICP-OES detection system to obtain accurate measurements of $\mathrm{I}^{-}$and $\mathrm{IO}_{3}{ }^{-}$chromatographic peaks at different retention times. Therefore, an analysis of the diffusion of $\mathrm{I}^{-}$and $\mathrm{IO}_{3}{ }^{-}$ions in bentonite clay was performed, with the results showing that lower accessible porosity was related to the anion exclusion effect and the size or hydrated radius of the ions. The effective diffusion coefficient $\left(D_{e}\right)$ and the capacity factor $(\alpha)$ obtained in this study could be used as input data for future safety assessments of radioactive waste disposal facilities. In conclusion, ${ }^{129} \mathrm{I}$ anions, in the form of $\mathrm{I}^{-}$and $\mathrm{IO}_{3}{ }^{-}$, are radionuclides that are critical factors to take into account when carrying out safety assessments of deep geological repositories for HLW, which should be a focus of future R\&D studies. In addition, our results confirm that Wyoming bentonite clay shows potential for use as a buffer/backfill material to counter the diffusion of radionuclides from containers used for storing HLW.

We have been relying on nuclear power for decades to meet our electricity needs. Today, governments around the word continue to invest in nuclear technology as part of their strategies to combat climate change and transition to low-carbon economies. Our role is to ensure there is a safe, long-term solution to the obstacles facing the containment and isolation of any spent nuclear fuel created by nuclear power generation, including what already exists today and any produced in the future.

Author Contributions: Conceptualization, S.-C.T., C.-P.L., Y.H. and N.-C.T.; methodology, C.-P.L., D.C., E.W., Z.W. (Ziteng Wang) and N.-C.T.; software, Z.W. (Zijin Wen), C.-P.L. and N.-C.T.; validation, E.W., Z.W. (Ziteng Wang), Y.S., D.C., N.-C.T. and S.-C.T.; formal analysis, F.Y., Y.-L.L., Y.S., D.C., C.-P.L. and N.-C.T.; investigation, Y.H., Y.S., F.Y. and Y.-L.L.; resources, N.-C.T. and S.-C.T.; data curation, F.Y., Y.-L.L., Y.S., D.C., Y.H. and Y.S.; writing—original draft preparation, C.-P.L. and N.-C.T.; 
writing —review and editing, C.-P.L. and N.-C.T.; visualization, Y.H., Y.S., F.Y. and Y.-L.L.; supervision, C.-P.L. and N.-C.T.; project administration, N.-C.T. and S.-C.T.; funding acquisition, N.-C.T. and S.-C.T. All authors have read and agreed to the published version of the manuscript.

Funding: This project was mainly supported by the Doctor Initial Financial Project (No. 1410000434), China Uranium Company and East China University of Technology United Project (No. NRE2021-10), and Jiangxi Province Graduate Student Creative Project (No. YC2021-S653). This project was financed in part by the Ministry of Science and Technology (MOST, Taiwan R.O.C.) and the Atomic Energy Council (AEC, Taiwan R.O.C.) through a two-year mutual fund program project under contract numbers 109-2623 -E-007 -006 -NU and 110-2623 -E-007 -004 -NU.

Institutional Review Board Statement: Not applicable.

Informed Consent Statement: Not applicable.

Data Availability Statement: The data presented in this study are available on request from the corresponding author.

Acknowledgments: The experimentation conducted in this study was assisted by Tsuey-Lin Tsai, YuHung Shih, and Liang-Cheng Chen, members of the Chemistry and Analysis Division of the Institute of Nuclear Energy Research, Taiwan. Assistance in conducting the experimental and instrumental analyses of this study was provided by the Department of Nuclear Environmental Science of the China Institute for Radiation Protection (CIRP) in Taiyuan, China, the Instrumentation Center at the National Tsing Hua University in Taiwan, and the National Synchrotron Radiation Research Center (NSRRC) in Taiwan, under the contract number 2020-1-123-5.

Conflicts of Interest: The authors declare no conflict of interest.

\section{References}

1. Taiwan Power Company. Preliminary Technical Feasibility Study for Final Disposal of Spent Nuclear Fuel-2009; Progress Report (Summary); Taiwan Power Company: Taipei, Taiwan, 2009.

2. Japan Nuclear Cycle Development Institute. Japan, H12: Project to Establish the Scientific and Technical Basis for HLW Disposal in Japan; Japan Nuclear Cycle Development Institute: Tokyo, Japan, 2000.

3. Yang, T.; Knutsson, S.; Liu, X. Swelling properties and permeability of expandable clays of potential use for nuclear waste disposal. J. Earth Sci. Geotech. Eng. 2016, 6, 9-61.

4. Cui, Y.J. On the hydro-mechanical behaviour of MX80 bentonite-based materials. J. Rock Mech. Geotech. Eng. 2017, 9, 565-574. [CrossRef]

5. Chen, Y.G.; Dong, X.X.; Zhang, X.D.; Ye, W.M.; Cui, Y.J. Cyclic thermal and saline effects on the swelling pressure of densely compacted Gaomiaozi bentonite. Eng. Geol. 2019, 255, 37-47. [CrossRef]

6. Chen, Y.; Cai, Y.Q.; Pan, K.; Ye, W.M.; Wang, Q. Influence of dry density and water salinity on the swelling pressure and hydraulic conductivity of compacted GMZ01 bentonite-sand mixtures. Acta Geotech. 2021, 1-18. [CrossRef]

7. Jan, Y.L.; Tsai, S.C.; Wei, Y.Y.; Tung, N.C.; Wei, C.C.; Hsu, C.N. Coupled mechanics, hydraulics and sorption properties of mixtures to evaluate buffer/backfill materials. Phys. Chem. Earth Parts A/B/C 2007, 32, 789-794. [CrossRef]

8. Jan, Y.L.; Tsai, S.C.; Hsu, C.N. Associating characterization of bentonite-based buffer/backfill materials by distribution ratio (Rd) and Plastic index (PI). J. Mar. Sci. Technol. 2007, 15, 17-23. [CrossRef]

9. Glaus, M.A.; Müller, W.; Van Loon, L.R. Diffusion of iodide and iodate through Opalinus Clay: Monitoring of the redox state using an anion chromatographic technique. Appl. Geochem. 2008, 23, 3612-3619. [CrossRef]

10. Van Loon, L.R.; Soler, J.M.; Jakob, A.; Bradbury, M.H. Effect of confining pressure on the diffusion of $\mathrm{HTO}^{, 36} \mathrm{Cl}^{-}$and ${ }^{125} \mathrm{I}^{-}$in a layered argillaceous rock (Opalinus Clay): Diffusion perpendicular to bedding. Appl. Geochem. 2003, 18, 1653-1662. [CrossRef]

11. Shi, Y.; Lee, C.P.; Yu, H.; Hu, Y.; Liu, H.; Tien, N.C.; Wang, Y.; Liu, W.; Kong, J. Study on Advection-Dispersion Behavior for Simulation of HTO and Se Transport in crushed granite. J. Radioanal. Nucl. Chem. 2021, 328, 1329-1338. [CrossRef]

12. Shih, Y.H.; Lee, I.H.; Ni, C.F.; Tsai, T.L.; Chen, L.C.; Lee, C.P.; Tsai, S.C.; Su, T.Y. Experimental and numerical investigations of 99 $\mathrm{TcO}_{4}{ }^{2-}$ diffusion in compacted SPV 200 bentonite. J. Radioanal. Nucl. Chem. 2018, 316, 1081-1089. [CrossRef]

13. Fan, Y.; Hou, X.; Fukuda, M.; Zheng, J.; Aono, T.; Chen, N.; Zhang, L.; Zhou, W. 129I in a sediment core offshore Fukushima: Distribution, source and its implication. Chemosphere 2020, 252, 126524. [CrossRef] [PubMed]

14. Li, H.H.; Zhao, S.W.; Jia, M.L. The study of safety assessment guide of HLW geologic disposal system. J. Nucl. Sci. Eng. 2016, 36, 313-322.

15. Zhang, S.; Xu, C.; Creely, D.; Ho, Y.F.; Li, H.P.; Grandbois, R.; Schwehr, K.A.; Kaplan, D.I.; Yeager, C.M.; Wellman, D. Iodine-129 and Iodine-127 speciation in groundwater at the Hanford Site, U.S: Iodate Incorporation into Calcite. Environ. Sci. Technol. 2013, 47, 9635-9642. [CrossRef] [PubMed]

16. Kimmig, S.R.; Thompson, C.; Baum, S.; Brown, C.F. Evaluation of iodine speciation and 129I/127I ratios at low concentrations in environmental samples using IC-ICP-MS. J. Radioanal. Nucl. Chem. 2021, 327, 929-937. [CrossRef] 
17. Bors, J.; Dultz, S.; Riebe, B. Organophilic bentonites as adsorbents for radionuclides: I. Adsorption of ionic fission products. Appl. Clay Sci. 2000, 16, 1-13. [CrossRef]

18. Riebe, B.; Bors, J.; Dultz, S. Retardation capacity of organophilic bentonite for anionic fission products. J. Contam. Hydrol. 2001, 47, 255-264. [CrossRef]

19. Yamaguchi, T.; Nakayama, S.; Nagao, S.; Kizaki, M. Diffusive transport of neptunium and plutonium through compacted sand-bentonite mixtures under anaerobic conditions. Radiochim. Acta 2007, 95, 115-125. [CrossRef]

20. Kong, J.; Lee, C.P.; Sun, Y.; Hua, R.; Liu, W.; Wang, Z.; Li, Y.; Wang, Y. Anion exclusion and sorption effect for compacted bentonite: The dependency of diffusion coefficients and capacity of HTO and Se (IV). J. Radioanal. Nucl. Chem. 2021, 328, 717-725. [CrossRef]

21. Lebeau, D.; Leroy, N.; Doizi, D.; Wu, T.D.; Guerquin-Kern, J.L.; Perrin, L.; Ortega, R.; Voiseux, C.; Fournier, J.B.; Potin, P.; et al. Mass spectrometry-based imaging techniques for iodine-127 and iodine-129 detection and localization in the brown alga Laminaria digitata. J. Environ. Radioact. 2021, 231, 106552. [CrossRef]

22. Zhang, M.; Hou, X.; Zhang, Z.; Zhang, L.; Chen, N.; Fang, M. Rapid Analysis of 129 I in Natural Water Samples Using Accelerator Mass Spectrometry. At. Spectrosc. 2021, 42, 190-196. [CrossRef]

23. Molera, M.; Eriksen, T. Diffusion of $22 \mathrm{Na}^{+}, 85 \mathrm{Sr}^{2+}, 134 \mathrm{Cs}^{+}$and $57 \mathrm{Co}^{2+}$ in bentonite clay compacted to different densities: Experiments and modeling. Radiochim. Acta 2002, 90, 753-760. [CrossRef]

24. Wang, T.H.; Payne, T.E.; Harrison, J.J.; Teng, S.P. Interactions involving strontium and various organic acids on the surface of bentonite (MX-80). J. Radioanal. Nucl. Chem. 2015, 304, 95-105. [CrossRef]

25. Lee, C.P.; Hu, Y.; Chen, D.; Tien, N.C.; Tsai, S.C.; Shi, Y.; Lee, I.H.; Ni, C.F. A statistical evaluation for comparable analysis for estimating diffusion coefficient of pertechnetate $\left(99 \mathrm{TcO}_{4}{ }^{-}\right)$in compacted bentonite. Minerals 2021, 11, 1075. [CrossRef]

26. Crank, J. The Mathematics of Diffusion, 2nd ed.; Clarendon Press: Oxford, UK, 1975.

27. ASTM. Standard Test Method for Distribution Coefficients of Inorganic Species by the Batch Method. Am. Soc. Test. Mater. 2010, C1733-10, C26, 1-8.

28. Lee, C.H.; Teng, S.P. A dual period diffusion model for measuring diffusion parameters. Waste Manag. 1993, 13, 15-24. [CrossRef]

29. Takeda, A.; Tsukada, H.; Takaku, Y.; Satta, N.; Baba, M.; Shinata, T.; Hasegawa, H.; Unno, Y.; Hisamatsu, S. Determination of iodide, iodate and total iodine in natural water samples by HPLC with amperometric and spectrophotometric detection, and off-line UV irradiation. Anal. Sci. 2016, 32, 839-845. [CrossRef] [PubMed]

30. Van Loon, L.R.; Soler, J.M.; Bradbury, M.H. Diffusion of $\mathrm{HTO}, 36 \mathrm{Cl}^{-}$and $125 \mathrm{I}^{-}$in Opalinus Clay samples from Mont Terri: Effect of confining pressure. J. Contam. Hydrol. 2003, 61, 73-83. [CrossRef]

31. Wigger, C.; Van Loon, L.R. Importance of Interlayer Equivalent Pores for Anion Diffusion in Clay-Rich Sedimentary Rocks. Environ. Sci. Technol. 2017, 57, 1998-2006. [CrossRef]

32. Nightingale, E.R., Jr. Phenomenological theory of ion solvation. Effective radii of hydrated ions. J. Phys. Chem. 1959, 63, 1381-1387. [CrossRef]

33. Yu, J.W.; Neretnieks, I. Diffusion and Sorption Properties of Radionuclides in Compacted Bentonite; SKB TR 97-12; Svensk Kärnbränslehantering AB: Stockholm, Sweden, 1997. 